\title{
PELATIHAN SCRAPBOOK ART SEDERHANA BERTEMA ALAM UNTUK MENINGKATKAN KETRAMPILAN MOTORIK HALUS ANAK
}

\author{
Enis Fitriani, Tisa Maharani, Marsuki \\ IKIP Budi Utomo \\ enisfitriani@budiutomomalang.ac.id, tisamaharani@budiutomomalang.ac.id, \\ marsukigani@budiutomomalang.ac.id
}

\begin{abstract}
Fine motor skills are needed by early childhood considering that fine motor skills are one part of the stages of child development. The objectives to be achieved in this Community Service program were to provide information, provide understanding, and provide experience in making scrapbook art to improve the fine motor skills of children at RA Sirrul Khuluq, Malang Regency. The target in this program was the teachers. This program had been carried out in the form of training where teachers get information or theories about scrapbooking and fine motor skills in children in general and provide understanding and experience about simple and interesting scrapbook art suitable for children with appropriate natural themes. It can be concluded that this community service activity has been successfully proven by the enthusiasm of the teachers to ask questions, share experiences, discussion, and participate in scrapbooking.
\end{abstract}

Keywords: scrapbook; skill; fine_motoric; training; pre-school

\section{ANALISIS SITUASI}

Raudhatul Athfal (RA) Sirrul Khuluq merupakan lembaga pendidikan pra-sekolah yang beralamatkan di Jalan Raya Sumbul Desa Klampok, Kecamatan Singosari, Kabupaten Malang, Jawa Timur, Indonesia. Lembaga pendidikan dengan NPSN 69898013 ini berstatus Terdaftar di Dinas Pendidikan Kabupaten Malang.

Lokasi Lembaga Pendidikan yang ini terletak di daerah pedesaan yang masuk perkampungan yang cukup jauh dari jalan raya utama yaitu Jl. Raya Mondoroko. Akses RA Sirrul Khuluq cukup mudah yaitu dapat ditempuh dengan angkutan umum dari Terminal Arjosari dan Terminal Lawang, atau dengan menggunakan kendaraan pribadi roda empat atau roda dua. Jalan raya utama menuju RA Sirrul Khuluq sangat padat oleh lalu lalang kendaraan pribadi, baik mobil dan sepeda motor, dan kendaraan umum seperti bus dan angkutan umum karena ini adalah jalur propinsi di wilayah Kabupaten Malang dari arah Surabaya ke di Kota Malang.
Kegiatan-kegiatan yang melibatkan orang tua murid di RA Sirrul Khuluq cukup banyak dan terstruktur. Ada kegiatan yang diselenggarakn oleh pihak RA Sirrul Khuluq seperti kegiatan peringatan hari-hari besar. Selain itu, ada juga kegiatan yang merupakan program kerja dari Paguyuban Orang Tua/Wali Murid seperti kegiatan parenting, bakti sosial, sharing ilmu kerajinan/masak, serta arisan.

Berdasarkan kegiatan-kegiatan yang sudah dilaksanakan satu tahun terakhir, belum pernah ada kegiatan kerajinan scrapbook. Menurut Isnaeni (2013) definisi scrapbook adalah seni menempel foto atau gambar di media kertas, dan menghiasnya hingga menjadi karya kreatif. Sedangkan menurut Himawan (2012) Scrapbook adalah kegiatan yang memiliki kegiatan pokok menyusun foto atau barang atau tulisan dalam sebuah album. Tahap-tahapan dapalam membuat scrapbook ini menggunakan kemampuan otot-otot kecil seperti jari-jemari dan tangan yang sering membutuhkan kecermatan dan koordinasi dengan tangan atau Gerakan motorik halus. Sujiono 
(2008:12.5) menyatakan bahwa motorik halus adalah gerakan yang hanya melibatkan bagian-bagian tubuh tertentu saja dan dilakukan oleh otot-otot kecil, seperti keterampilan menggunakan jari jemari tangan dan gerakkan pergelangan tangan yang tepat. Sedangkan menurut Sumantri (2005) motorik halus atau (fine motoric) adalah pengorganisasian penggunaan sekelompok otot-otot kecil seperti jari-jemari dan tangan yang sering membutuhkan kecermatan dan koordinasi dengan tangan, keterampilan yang mencakup pemanfaatan menggunakan alat-alat untuk mengerjakan suatu objek. Namun tidak semua anak memiliki kematangan untuk menguasai kemampuan ini pada tahap yang sama.

Setelah kami berdiskusi dengan guruguru di RA Sirrul Khuluq tentang masalah kegiatan belajar mengajar dan perkembangan kemampuan anak, banyak pertanyaan muncul terutama bagaimana cara meningkatkan kemampuan motorik halus, sehingga kami terdorong untuk dapat mengadakan pelatihan untuk meninngkatkan kemampuan motorik halus pada anak melalui scrapbook art, mengingat scrapbook art adalah seni menempel foto atau gambar di media kertas atau media lain yang murah dan mudah didapat, dan menghiasnya hingga menjadi karya kreatif. Tema alam kami pilih karena tema alam terdapat dalam kurikulum pembelajaran dan gambar serta kelengkapan bahan bertema alam lebih mudah didapatkan di sekitar kita.

Tim pelaksana pengabdian kepada masyarakat telah melakukan diskusi baik secara langsung maupun tidak langsung melalui WhatsApp dengan Kepala RA Sirrul Khuluq mengenai rencana program pengabdian kepada masyarakat ini. Hasil dari diskusi tersebut adalah adanya kesepakatan bahwa perlunya diadakan kegiatan sosialisasi scrapbook dan pelatihan pebuatan scrapbook. Dengan kata lain, solusi yang ditawarkan Tim Pelaksana Pengabdian kepada Masyarakat diterima dengan baik.

\section{METODE PELAKSANAAN}

Kegiatan Pengabdian kepada Masyarakat ini dilaksanakan selama tiga hari yaitu pada tanggal 24-25 Februari 2017 yang bertempat di RA Sirrul Khuluq Jalan Raya Sumbul Desa Klampok, Kecamatan Singosari, Provinsi Jawa Timur, Indonesia.

Sasaran dalam kegiatan Pengabdian kepada Masyarakat ini adalah para guru RA Sirrul Khuluq Kabupaten Malang.

Adapun prosedur pelaksanaan kegiatan yang diadakan adalah berbentuk: 1) sosialisasi, di mana guru akan mendapatkan informasi atau teori tentang scrapbook; serta 2) pelatihan, bagaimana membuat scrapbook art sederhana yang sesuai untuk anak usia dini.

Metode pelatihan yang digunakan pada pelatihan ini adalah ceramah pada sesi penyajian materi/teori dan demonstrasi pada sesi praktik. Dalam metode ini pemateri lebih banyak bercerita/menjelaskan sedangkan peserta aktif mendengarkan. Sedangkan metode demonsrasi merupakan metode pembelajaran yang dilakukan dengan mempertunjukkan sesuatu (atau cara melakukan sesuatu secara runtun dan benar) dengan tujuan peserta belajar memahami lebih mudah.

Pada pelaksanaannya tim pelaksana pengabdian kepada masyarakat melakukan langkah berikut.

1. Penyampaian materi sosialisasi secara lisan kepada peserta. Untuk mengetahui kemampuan awal peserta terkait materi penyuluhan dan pelatihan yang akan disampaikan dilakukan pre-test. Sesaat sebelum materi diberikan peserta akan mengerjakan pre-test sesuai materi yang akan diberikan. Ini berarti ada dua pre-test yang telah dipersiapkan untuk dua materi presentasi yang berbeda. Adapun materi yang diberikan dalam kegiatan pengabdian pada masyarakat ini adalah Mengenal Scrapbook Art dan Perkembangan Ketrampilan Motorik Halus pada Anak. 
2. Pelatihan pembuatan Scrapbook Sederhana Bertema Alam untuk Pembelajaran TK.

3. Evaluasi kegiatan pengabdian kepada masyarakat dengan instrument post-test dan lembar pengamatan. Post-test dilakukan untuk mengetahui kemampuan akhir peserta terkait materi sosialisasi dan pelatihan yang telah disampaikan. Sama halnya dengan pre-test, post-test pun juga ada tiga yang masing-masing dikerjakan setelah masing-masing materi diberikan. Lembar pengamatan digunakan selama penyuluhan dan khususnya pada pelatihan saat praktek membuat scrapbook, dengan dilengkapi foto-foto dokumentasi kegiatan.

\section{HASIL DAN PEMBAHASAN}

Penyampaian materi penyuluhan secara lisan kepada para guru di RA Sirrul Khuluq

Kegiatan pengabdian pada masyarakat yang telah dilakukan adalah penyuluhan di mana wali murid akan mendapatkan informasi atau teori tentang scrapbook untuk anak usia dini dan bagaimana membuatnya untuk diajarkan kepada murid-murid di RA Sirrul Khuluq.

Sebelum materi diberikan peserta mengerjakan pre-test sesuai materi. Adapun pertanyaan-pertanyaanya tersaji di Tabel 1 .

Tabel 1. Pertanyaan Pre-Test dan Post-Test Materi 1

\begin{tabular}{|c|c|c|}
\hline No. & Pertanyaan & Jawaban \\
\hline 1. & $\begin{array}{l}\text { Apakah anda mengenal } \\
\text { scrapbook art? } \\
\text { Jika Ya, jelaskan secara } \\
\text { singkat! }\end{array}$ & Ya/Tidak* \\
\hline 2. & $\begin{array}{l}\text { Apakah anda mengetahui apa } \\
\text { keterampilan motorik halus? } \\
\text { Jika } Y a \text {, jelaskan secara } \\
\text { singkat! }\end{array}$ & Ya/Tidak* \\
\hline 3. & $\begin{array}{l}\text { Apakah anda tahu kegiatan } \\
\text { apa saja yang melibatkan } \\
\text { motorik halus? } \\
\text { Jika } Y a \text {, sebutkan berapa dan } \\
\text { sebutkan! (Minimal 3) }\end{array}$ & Ya/Tidak* \\
\hline
\end{tabular}

*Coret yang tidak perlu

Dari 5 peserta yang hadir dan mengisi pre-test materi 1 menunjukkan bahwa seluruh peserta menjawab tidak pada tiap pertanyaan. Hal ini menunjukkan kebutuhan akan informasi mengenai scrapbook art dan perkembangan motorik halus dibutuhkan.

Materi yang disampaikan lebih pada mengenal scrapbook art dan perkembangan ketrampilan motorik halus pada anak mengingat hampir semua aktivitas bermain anak melibatkan keterampilan motorik halus seperti:
a. memegang mainan
b. Menulis
c. menyobek kertas
d. bermain piano
e. dan sebagainya.

Banyak kegiatan yang bisa dilakukan anakanak untuk melatih keterampilan motorik halus di sekolah, salah satunya melalui scrapbook art.

Saraf motorik halus dapat dilatih dan dikembangkan melalui kegiatan dan rangsangan yang kontinu secara rutin seperti:
a. menggunting sesuai pola
b. membuat garis
c. mewarnai
d. melipat kertas
e. menempel
f. menyusun benda-benda kecil
g. dan sebagainya

yang mana kegiatan-kegiatan tersebut ada dalam kegiatan scrapbook art. Hal ini berarti, membuat scrapbook art dapat mengembangkan daya kreativitas anak karena kemampuan motorik halus berhubungan dengan keterampilan fisik yang melibatkan otot kecil dan koordinasi matatangan di mana daya kreativitas anak otomatis terus terasah.

Adapun beberapa ide untuk scrapbook antara lain adalah mengumpulkan foto-foto sejak anak lahir, dalam membuat scrapbook guru bisa:

a. mengumpulkan foto-foto

b. meminta anak untuk menempelkan

c. menuliskan komentar-komentar lucu

d. menggunakan sticker 
e. menggunakan kertas berwarna-warni

f. menggunakan wool

g. atau hiasan lainnya

Setelah materi disampaikan oleh pemateri, ada sesi tanya jawab, sebanyak tiga peserta bertanya mengenai bagaimana cara menggunakan bahan-bahan yang ada di sekitar untuk scrapbook art, bagaimana tips memilih kertas-kertas yang berkualitas, dan juga hal-hal apa saja yang bisa terjadi jika keterampilan motorik halus tidak dibiasakan.

Ketika pemateri selesai memberikan jawaban atas semua pertanyaan, Tim Pengabdian kepada Masyarakat membagikan lembar post-test (dengan pertanyaan yang sama dengan pre-test) untuk mengetahui kemampuan akhir peserta terkait materi yang telah disampaikan. Hasilnya cukup menggembirakan, sebanyak $80 \%$ atau 4 orang peserta mampu menjawab 3 pertanyaan dengan benar, $20 \%$ atau 1 orang menjawab 2 pertanyaan dengan benar.

\section{Pelatihan pembuatan scrapbook art sederhana bertema alam untuk pembelajaran TK}

Rangkaian kegiatan pengabdian pada masyarakat selanjutnya adalah pelatihan pembuatan scrapbook art sederhana bertema alam untuk pembelajaran TK. Tidak seperti pada materi sebelumnya, kali ini pemateri langsung memberikan materi yang berupa contoh bagaimana cara membuat scrapbook.

Pembuatan Scrapbook Art Sederhana Bertema Alam untuk Pembelajaran TK

Berikut adalah langkah-langkah yang perlu dilakukan sebelum membuat scrapbook.

1. Memilih tema dan model scrapbook

Memilih tema merupakan langkah awal yang harus dilakukan dalam membuat scrapbook. Pemilihan tema akan memengaruhi pemilihan bahan-bahan yang diperlukan dalam proses pembuatan karya. Sesuai dengan tema yang ingin diangkat dalam pembuatan scrapbook dalam pengabdian masyarakat ini, yaitu tema alam dan lingkungan, maka bahan-bahan yang dipilih dapat disesuaikan.

2. Menyiapkan Alat dan Bahan

Berikut alat-alat dan bahan-bahan yang perlu disiapkan dalam pembuatan scrapbook.

a. Kertas

Kertas yang digunakan dapat beragam sesuai dengan kebutuhan dan ketersediaan. Berikut macam-macam kertas yang dapat dipilih sebagai bahan.

1) kertas hvs/ kertas spectra

2) karton \& kertas samson

3) kertas concorde

4) kertas dari buku kotak-kotak

5) karton duplek

a. Lem Fox/Lem Uhu

b. Gunting

c. Kawat

d. Selotip motif

e. Double tape, scotch double tape

f. Kertas hias

\section{Menentukan ukuran}

Ada dua ukuran standar untuk scrapbook, yaitu 21,25 x 27,5 cm dan 30x30 $\mathrm{cm}$ serta sejumlah ukuran khusus. Gaya album yang inginkan dapat menentukan ukuran apa yang dipilih. Model atau jenis album yang akan digunakan dapat beragam. Jenis album yang dipilih nantinya akan dijadikan sebagai platform untuk karya yang dibuat. Bentuk dan ukuran, akan berpengaruh terhadap jenis dan jumlah bahan yang disediakan. Meskipun dapat dibeli, tidak menutup kemungkinan untuk dibuat sendiri dan disesuaikan dengan kreativitas masingmasing.

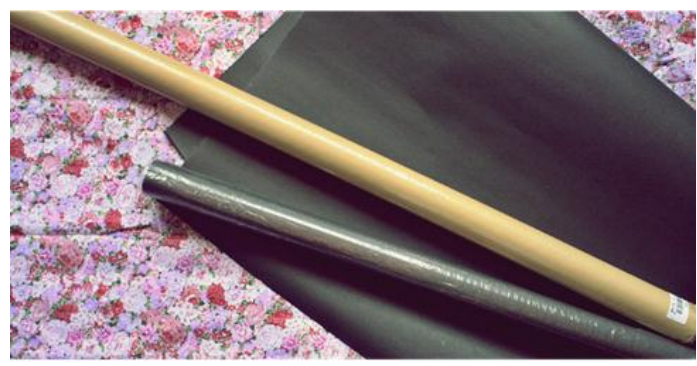

Gambar 3. Kertas karton dan kertas samson 

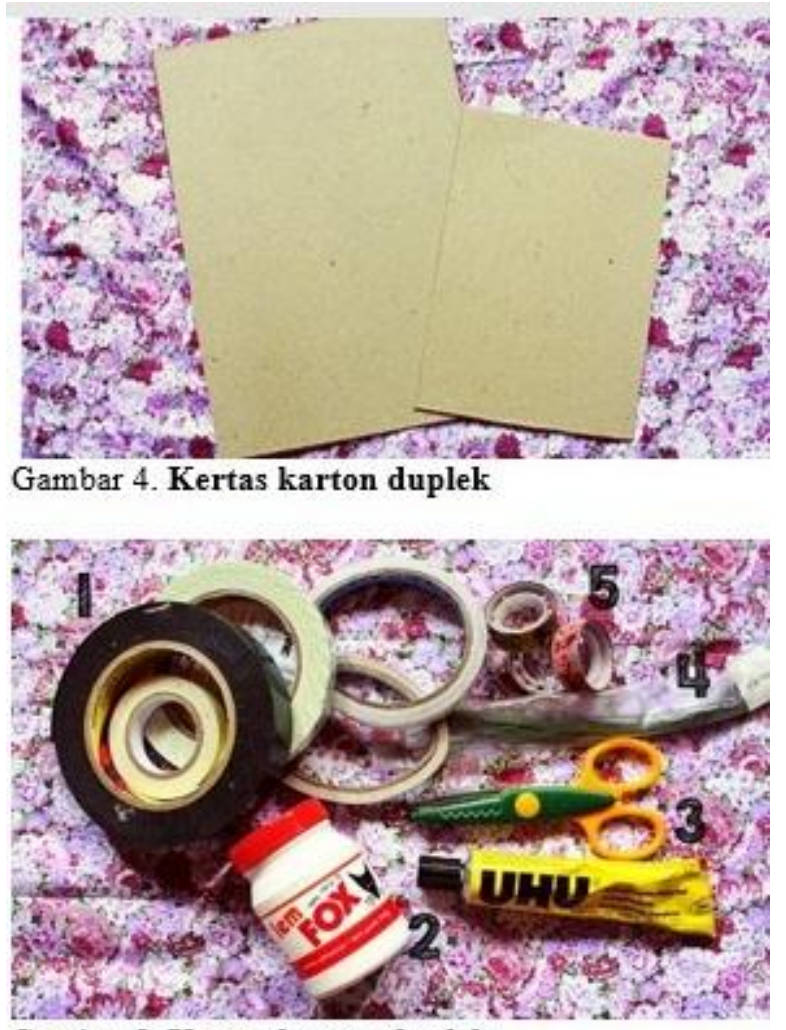

Gambar 5. Kertas karton duplek

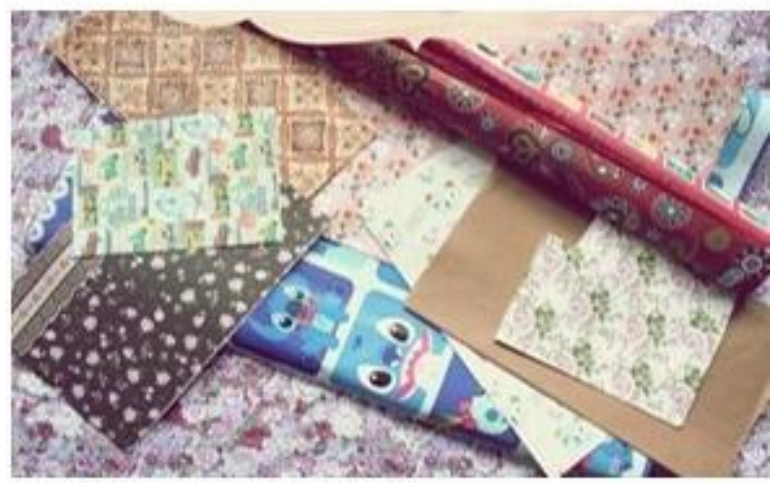

Gambar 6. Kertas hias/kado

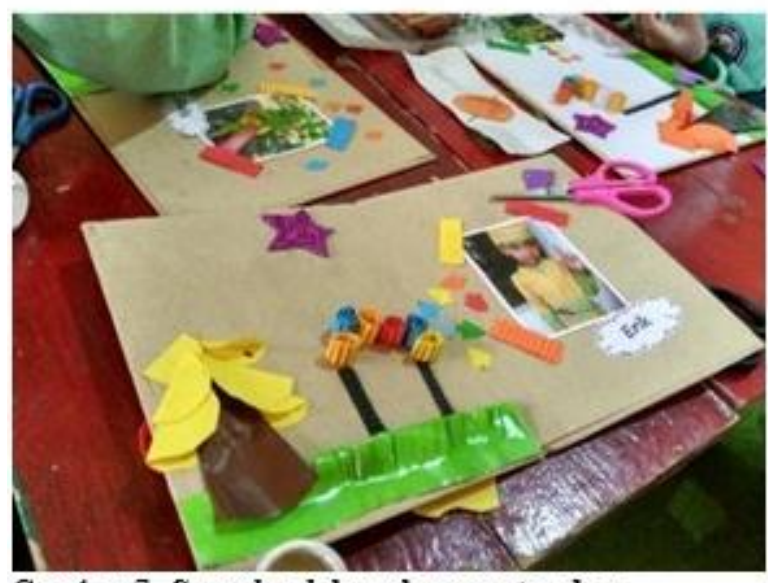

Gambar 7. Scrapbook berukuran standar
4. Memilih kertas yang diinginkan dan menghias

Pada tahapan ini, pembuat scrapbook bebas berkreasi. Pada kegiatan kali ini kertaskertas yang digunakan untuk menghias ialah kertas-kertas berwarna atau bergambar menarik yang mayoritas ialah kertas-kertas hias dari bahan bekas. Sesuai instruksi dan tema yang diangkat dalam pengabdian masyarakat tersebut, maka hiasan dibuat menyesuaikan tema alam.

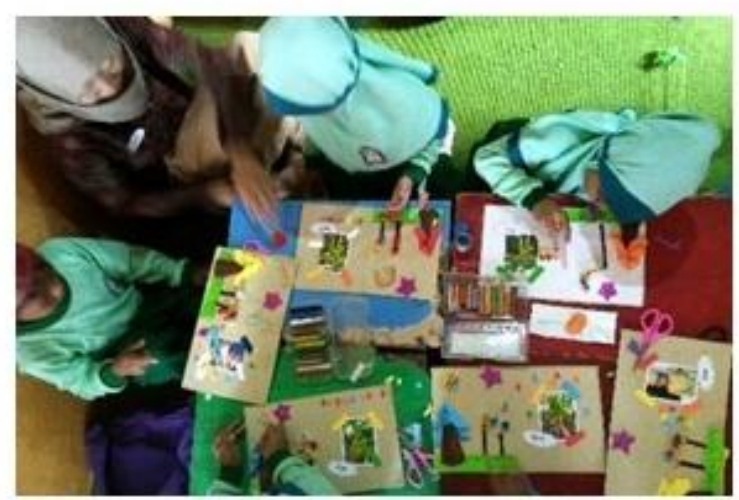

Gambar 8. Peserta berkolaborasi dengan muridmuridnya membuat scrapbook

Setelah peserta memperhatikan bagaimana contoh dibuat, peserta mempraktikkannya.

\section{Evaluasi kegiatan pengabdian kepada masyarakat}

Evaluasi kegiatan pengabdian kepada masyarakat berdasarkan hasil post-test dan lembar pengamatan yang digunakan selama praktik. Berdasarkan hasil dari post-test pada dapat disimpulkan bahwa pengetahuan guru tentang scrapbook art dan ketrampilan motorik halus sudah bertambah berdasarkan hasil post-test yang menunjukkan $80 \%$ atau 7 orang peserta mampu menjawab 3 pertanyaan dengan benar, $20 \%$ atau 2 orang menjawab 2 pertanyaan dengan benar.

Sedangkan untuk pelataihan pembuatan scrapbook art dievaluasi dengan menggunakan lembar pengamatan yang digunakan selama praktek. Aktivitasaktivitas peserta yang diamati tersaji pada Tabel 2. 
Tabel 2. Lembar Pengamatan Peserta

\begin{tabular}{|c|c|c|}
\hline No. & Aktivitas & Tidak ----> Ya? \\
\hline 1. & $\begin{array}{l}\text { Peserta memperhatikan } \\
\text { Pemateri saat menjelaskan } \\
\text { dan memberikan contoh. }\end{array}$ & $\begin{array}{lllll}1 & 2 & 3 & 4 & 5\end{array}$ \\
\hline 2. & $\begin{array}{l}\text { Peserta bersedia memilih } \\
\text { pasangan kerja atau } \\
\text { membuat tim dengan suka } \\
\text { rela. }\end{array}$ & $\begin{array}{lllll}1 & 2 & 3 & 4 & 5\end{array}$ \\
\hline 3. & $\begin{array}{l}\text { Peserta bersedia } \\
\text { mempraktikkan apa yang } \\
\text { ditugaskna oleh Pemateri. }\end{array}$ & $\begin{array}{lllll}1 & 2 & 3 & 4 & 5\end{array}$ \\
\hline
\end{tabular}

*Lingkari respon yang sesuai dari skala 1-5

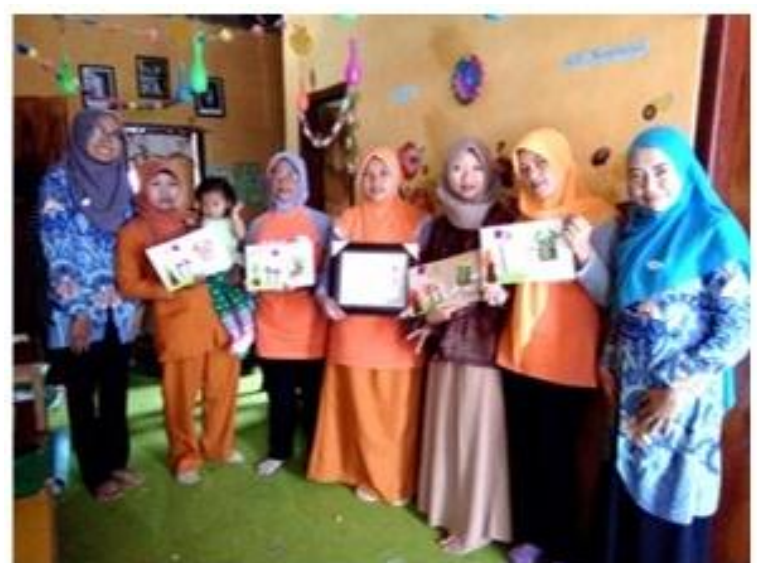

Gambar 9. Foto bersama tim pelaksana pengabdian kepada masyarakat dengan peserta

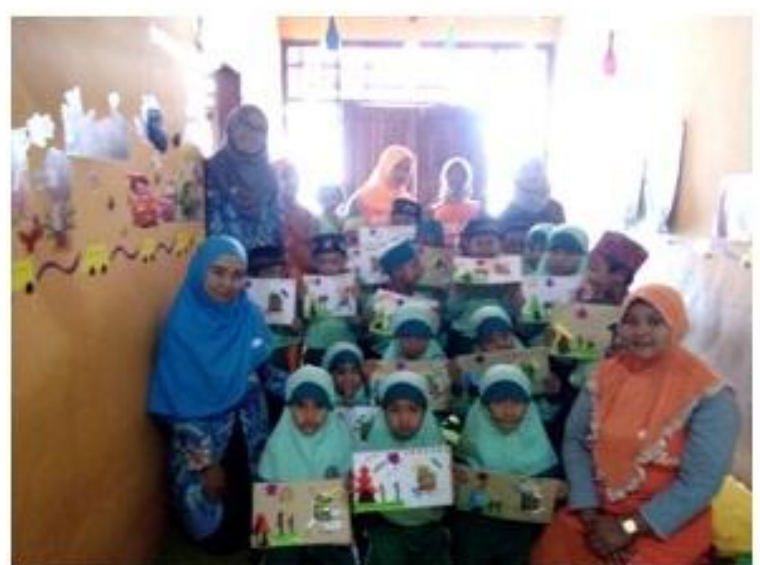

Gambar 10. Foto bersama tim pelaksana pengabdian kepada masyarakat dengan guru dan murid RA Sirrul Khuluq

Berdasarkan hasil pengamatan, didapatkan bahwa dalam skala 1-5, peserta memperhatikan Pemateri saat menjelaskan dan memberikan contoh bernilai 4, peserta bersedia membetuk pasangan kerja dengan suka rela bernilai 5, dan Peserta bersedia mempraktikkan apa yang ditugaskna oleh Pemateri bernilai 4. Hal ini menunjukkan bahwa kegiatan pengabdian kepada masyarakat ini direspon baik oleh peserta kegiatan ini.

\section{KESIMPULAN}

Tim Pelaksana Pengabidan kepada Masyarakat dari IKIP Budi Utomo telah berhasil melaksanakan sosialisasi dan pelatihan scrapbook art sederhana bertema alam untuk meningkatkan kemampuan motorik halus anak di RA Sirrul Khuluq, Sumbul, Klampok, Singosari Kabupaten Malang pada tanggal 24-25 Februari 2017. Seluruh peserta dapat melaksanakan dengan baik tiap tahapan kegiatan ini. Mitra mampu memfasiliasi penyediaan ruang, kebutuhan akan sumber daya listrik, dan menginformasikan adanya kegiatan ini kepada orang tua/wali murid. Hasil yang diharapkan pun terwujud, pengetahuan guru tentang scrapbook art dan ketrampilan motorik halus bertambah, mau ikut serta dalam mempraktikkan dengan baik dan indah, bahkan para murid bersedia dilibatkan dalam pembuatan scrapbook. Dengan kata lain kegiatan pengabdian kepada masyarakat ini direspon baik oleh peserta dan Mitra dan berjalan lancar.

Tentunya keberlanjutan dalam mempraktikkan apa yang sudah diinformasikan, disarankan, dan dipraktikkan dalam kegiatan ini diharapkan dapat dilakukan oleh para guru. Ada juga permintaan dari para guru kepada tim pengabdian yakni pemateri untuk menindak lanjuti kegiatan pengabdian kepada masyarakat ini dengan memberi informasi mengenai tempat dan kegiatan untuk memperoleh pelatihan yang sesuai dengan materi PAUD.

\section{Ucapan Terima Kasih}

Ucapaan terima kasih ditujukan kepada Ketua Pusat Penelitian dan Pengabdian kepada Masyarakat (P2M) IKIP Budi Utomo, 
Malang, dan Mitra, Kepala RA Sirrul Khuluq, Sumbul, Klampok, Singosari, Kab. Malang karena telah memberikan dukungan atas terselenggaranya kegiatan pengbdian kepada masyarakata ini.

\section{DAFTAR PUSTAKA}

Himawan, Ina. 2012. Melatih Kreativitas Melalui Scrapbooking. http://www.infoanak.com/melatihkreativitas-melalui-scrapbooking/

https://en.wikipedia.org/wiki/Scrapbooking accessed on 17 February 2017

Hurlock (1996) in Loelha, Mely. 2013. Hakikat Perkembangan Motorik Halus Anak Usia Dini. http://melyloelhabox.blogspot.co.id/20 13/05/hakikat-perkembangan-motorik$\underline{\text { halus-anak.html }}$

Isnaeni, Iis. 2013. Scrapbook. http://isnaeniiis318.blogspot.co.id/2013/02/scrapboo k-a.html

Musbikin, Imam. 2012. Tumbuh Kembang Anak. Jogjakarta: Flash Book.

Saraswati, Widasari. 2012. Ide-Ide Kreatif Menghabiskan Weekend. http://widasarisaraswati.blogspot.co.id/ 2012/07/ide-ide-kreatif-menghabiskanweekend.html

Sujiono, Bambang $(2008: 12.5)$ in Loelha, Mely. 2013. Hakikat Perkembangan Motorik Halus Anak Usia Dini. http://melyloelhabox.blogspot.co.id/20 13/05/hakikat-perkembangan-motorikhalus-anak.html

Sumantri, 2005. Model Pengembangan Keterampilan Motorik Anak Usia Dini. Jakarta: Depdiknas,Dirjen Dikti.

Suryani, Tatik. 2014. Metode Pembelajaran dalam Modul Pelatihan Pengembangan
Ketrampilan Dasar Teknik Instruksional. Surabaya: Koordinasi Perguruan Tinggi Swasta Wilayah VII

Yuniarni, Desni. 2010. Metode Pengembangan Anak Usia Dini: Pontianak. 